\title{
EVALUATION OF PUBLIC PROCUREMENT MECHANISM FOR SUSTAINABLE DEVELOPMENT IN BANGLADESH
}

\author{
Mohammad Abdul Mannan ${ }^{1}$, Zahidul Islam ${ }^{2}$ \\ ${ }^{I}$ Department of Electrical \& Electronic Engineering, Dhaka University of Engineering \& Technology, Gazipur, \\ mannan489@yahoo.com \\ ${ }^{2}$ Department of Anthropology, University of Dhaka
}

\begin{abstract}
Transparency, accountability and efficiency in PPM is the vital requirement for sustainable development of all sectors of a developing country like Bangladesh. Developing countries utilize huge amount of their national budget in development projects through procurement of goods, works and services. For sustainable development, proper utilization of this huge amount of national budget must be ensured through establishing sound (PPM). This paper presents a study in PPM of Bangladesh and corresponding empirical outcomes with object oriented suggestions for sustainable development. Participant Observation Method, Case Study Method and Questionnaire techniques are used to collect primary data. Questionnaire comprising of 29 queries is administered among 60 respondents involved in public procurement. Author has been involved in public procurement mechanism, as member (TEC/PEC) and consultant for the last ten years to study the system as a participant \& case study observer. Secondary data is collected from related books, journals and documents of GoB. Empirical outcomes and object oriented suggestions are obtained through analysis of data. Final outcomes are evaluated lacks, gaps, problems etc of existing PPM and specific suggestions for sustainable development in Bangladesh.
\end{abstract}

\section{Keywords:}

Sound PPM: A public procurement mechanism which ensures transparent procurement process, best value for money, quality and standard of procured goods / works / services, accountability and strongly resist corruptions and misuse of national budget.

Poor PPM: A PPM which includes opaque procurement process, corruption favoring rules and procedures, fails to ensure best value for money, transparency and accountability, quality and standard of procured goods/works/services.

\section{INTRODUCTION}

As a developing country, Bangladesh utilizes approximately $75 \%$ of national budget in development projects. This huge amount of national budget has been used for procurement of goods, works and services. For sustainable development of Bangladesh, we should ensure proper utilization of this major portion of our national budget ie ensure best value for money through establishing sound PPM. But due to systemic deficiencies including opaque procurement practices, outdated procurement rules and procedures, inadequate management capacity, lack of transparency and accountability mechanisms, pervasive rent-seeking, corruption, fraudulent/collusive/ coercive practices, dishonesty, lack of morality and ethics etc, a large sum of money is wasted[2]. This leads not only to misuse of scarce public resources, domestic \& foreign aids, but also leads to acquisition of poor quality of goods, works and services [2]. At a more fundamental level, it causes erosion of public confidence and deterioration of investment climate i.e. poor PPM is the main barrier in our national development.

On the other hand, sound SPPM promises significant benefits for sustainable development in Bangladesh. These include economy, efficiency and transparency in public procurement leading to timely and cost effective implementation of development projects[2]. It has the potential for enhancing Bangladesh's aid utilization capacity, creating opportunities for increasing foreign aids, reducing cost of doing business in Bangladesh and improving investment climate, for the better interest of the state as well as the people or mankind. It offers a promise for developing the capacity of domestic contracting and consulting industries/firms for entry into the regional and global markets [2]. To achieve sound PPM, GoB, as a part of Public Procurement reform activities, developed and implemented PPR-03 in 2003, PPA-06, PPR-08 and PPR-11. But expected goal is not yet achieved. Present research was aimed to conduct a systematic study and evaluation of existing 
public procurement mechanism of GoB and to develop significant suggestions for sustainable development in Bangladesh.

\section{METHODOLOGY}

Participant Observation Method, Case Study Method and Questionnaire techniques of Survey Method are used to collect primary data from public bodies like Rural Electrification Board, Bangladesh Bank, Bangladesh Rice Research Institute, Dhaka University of Engineering \& Technology, Bangladesh Power Development Board, Security Printing Corporation Ltd, Telephone Shilpa Songstha etc. As a member of TEC/PEC and consultant to many engineering projects. Participant observation and case study methods had been used to know activities, involvement, and professionalism of prevailing PPM for the last ten years. Qualitative outcomes, from this long study are incorporated in construction of questionnaire. Following steps are followed in construction of questionnaire [4].

(i) As per definition of the problem to be investigated, data requirement is fixed. And qualitative outcomes from case study and participant observation are incorporated.

(ii) Type of questionnaire (closed/open ended) is decided.

(iii) Topics of questionnaire are outlined and questions are written on three areas; general queries on PPR, drawbacks of PPM, suggestions for Sustainable Development in Bangladesh[5].

(iv) Questionnaire are edited for technical defects or bases that reflect personal values.

(v) Questions are pre-tested to know how well to work.

(vi) After pretest, final edition is made of ensure that the questionnaire is ready for administration. This includes a close look at the content, sequence of questions, appearance and clarity of the procedure for using the questionnaire.

(vii) Finally the questionnaire is formulated to made it reliable and valid. To do a satisfactory formulation job, procedural check lists are considered.

\section{QUESTIONNAIRE}

Questionnaire technique of survey method is used to collect primary data from GoB's procurement sector. Sample random sampling method is used to select 60 respondents; 40 from procuring entity and 20 from suppliers/contractors/consultants engaged in development projects. For limitation of paper size, questionnaire format comprising of 27 queries; 9 for assessment of PPR, 9 to find out drawbacks of PPR and 9 for development of suggestions to establish sound PPM that was administered on 6 respondents is not presented(available in ref-1).

\section{STATISTICS OF RESPONDENTS}

Demographic information and statistics of respondents are shown below:
1. Code No

2. Category

3. Age

4. Education

5. Religion

6. Marital status

7. Sex

8. Occupation (position)

Table-1: Age of Respondents

\begin{tabular}{|l|l|l|}
\hline Age structure & $\begin{array}{l}\text { No of } \\
\text { respondent }\end{array}$ & Percentage (\%) \\
\hline Age up to 30 years & 5 & 8.33 \\
Age 30 to 35 years & 10 & 16.67 \\
Age 36 to 40 years & 10 & 16.67 \\
Age 41 to 45 years & 15 & 25 \\
Age 46 to 50 years & 15 & 25 \\
Above 50 & 5 & 8.33 \\
\hline $\mathrm{N}$ & 60 & \\
\hline
\end{tabular}

Table 1 shows that age group of 41 to 50 predominating public procurement process.

Table - 2: Education of Respondents

\begin{tabular}{|l|l|l|l|}
\hline \multicolumn{2}{|l|}{ Level of education } & $\begin{array}{l}\text { No } \\
\text { respondent }\end{array}$ & of \\
\hline 01 & B.Sc. Engg. & 40 & 66.67 \\
02 & degree & 10 & 16.67 \\
03 & M.Sc. & 6 & 10 \\
04 & Engg./Ph.D. & 4 & 6.66 \\
& Masters & & \\
& degree & & \\
& Diploma & & \\
& Engg./Pass & & \\
& course & & 100 \\
\hline & N & 60 & \\
\hline
\end{tabular}

Table 2 shows that B.Sc. Engineers are major resources (66.67\%) involved in existing PPM.

Table - 3: Religion, Marital status and Sex of Respondents

\begin{tabular}{|l|l|l|}
\hline $\begin{array}{l}\text { Religion, Marital status } \\
\text { and Sex }\end{array}$ & $\begin{array}{l}\text { No of } \\
\text { respondent }\end{array}$ & \\
\hline Islam & 58 & 96.67 \\
Others & 2 & 3.33 \\
Married & 59 & 98.33 \\
Unmarried & 1 & 1.67 \\
Male & 59 & 98.33 \\
Female & 1 & 1.67 \\
\hline N & 60 & 100 \\
\hline
\end{tabular}


Table 3 shows that Muslims, Married \& Male officers are predominating in existing PPM. Number female officer is very low.

Table - 4: Position of Respondents

\begin{tabular}{|l|l|l|l|}
\hline \multicolumn{2}{|l|}{ Position Structure } & No of respondent & Percentage (\%) \\
\hline 1 & national scale No. 2 & 10 & 16.67 \\
2 & national scale No. 3 & 20 & 33.33 \\
3 & national scale No. 4 & 10 & 16.67 \\
4 & national scale No. 5 & 10 & 16.67 \\
5 & national scale No. 6 & 3 & 5.00 \\
6 & national scale No. 7 & 3 & 5.00 \\
7 & national scale No. 8 & 2 & 3.33 \\
8 & national scale No. 9 & 2 & 3.33 \\
\hline $\mathrm{N}$ & & 60 & 100 \\
\hline
\end{tabular}

Table 4 shows that officers of national grade no 3 have highest position and grades $2,4 \& 5$ have second position.

\section{EMPIRICAL OUTCOMES}

Empirical outcomes from the questionnaire administered on selected respondents are presented below: for limitation of paper size, only outcomes on queries of special importance are presented below (interested readers on requested read ref 1).

Q-1 Tendering process is influenced by coercive/ collusive /fraudulent practices.

Ans.: yes / no / frequently / rarely

Graphical Representation

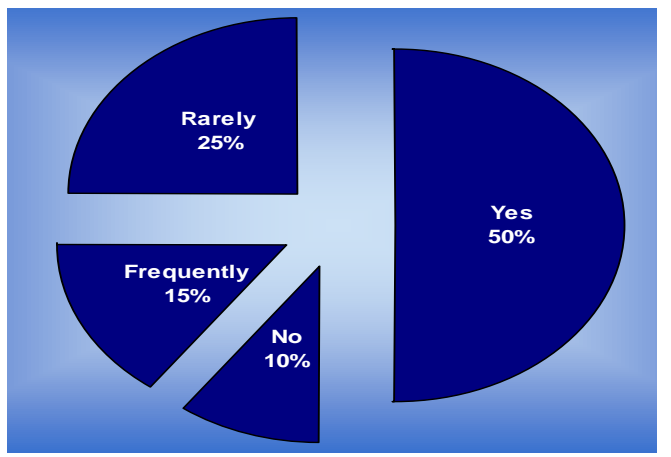

So tendering process should be free from coercive/ collusive /fraudulent practices.

Q.-2 All universities should have sufficient courses (likely at least 3 courses, each having 3 credits in graduation level) on education and practices on honesty, morality and professional ethics. Course contents should be taken from religions and from life history of famous personnel of the history.

Ans.: Yes / No / Partially

Graphical Representation

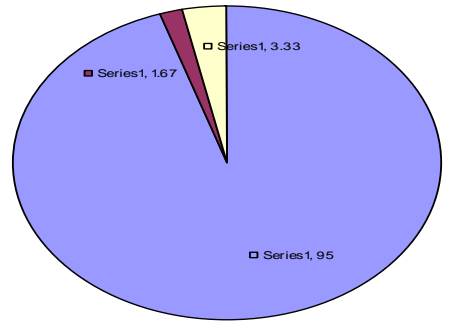

Which show that $95 \%$ of respondents are completely agreed with the suggestion of "All university should have sufficient courses (likely at least 3 courses, each having 3 credits in graduation level) on education and practices on honesty, morality and professional ethics. Course contents should be taken from religions and from life history of famous personnel of the history".

Q.-3 As approximately $75 \%$ of national budget is utilized in development projects, and engineers are mainly involved in development project, all engineering graduation courses should include a course on Public Procurement Management. Ans.: Yes / No/ Partially

Graphical Representation

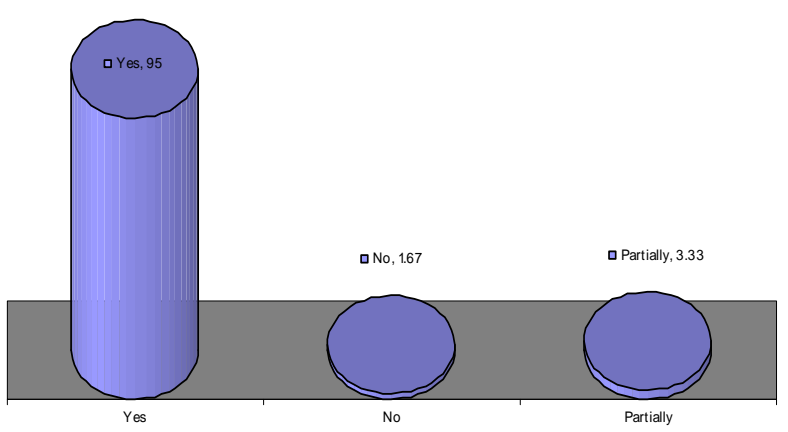

Which show that $95 \%$ of respondents are agreed with the suggestion of "All engineering graduation courses should include a course on Public Procurement Management".

Q.-4 All universities, providing engineering graduation, must ensure educational quality and standard up to professional level. To achieve such level of standard, Universities must have co-operation with industries, so that students can conduct UG/PG research on industry's need based projects, that is on real time project not only on academic projects.

Ans.: Yes / No/ Partially

Graphical Representation 


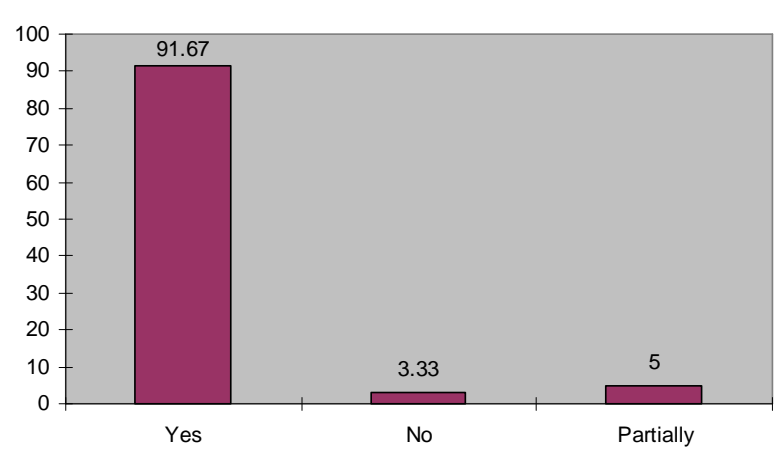

Graph shows that $91.67 \%$ of respondents agree with the suggestion- "All universities, providing Engineering graduation, must ensure educational quality and standard up to professional level. To achieve such level of standard, universities must have co-operation with industries, so that students can conduct UG/PG research on industry's need based projects, that is on real time project not only on academic projects".

Q.-5 There should be a realistic procurement plan for each development project, the procurement plan should be developed by team works, team members should have experience on implementation, installation, testing, commissioning and operation maintenance of such projects.

Ans.: Yes / No/ Partially

Graphical Representation

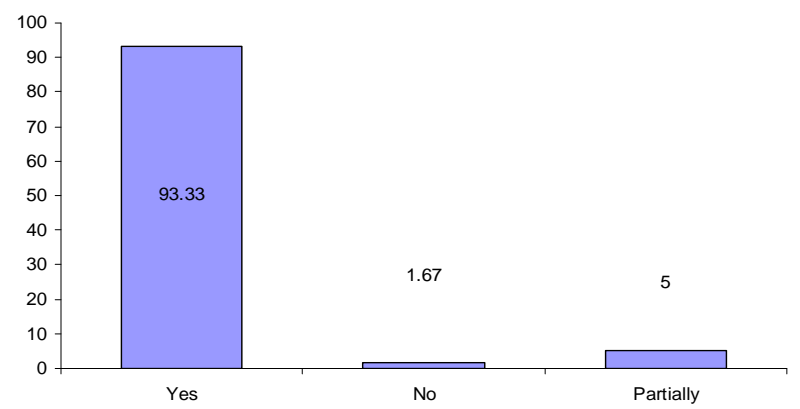

Graph show that $93.33 \%$ of respondents agree with the suggestion - "There should be a realistic procurement plan for each development project, the procurement plan should be developed by team works, and team members should have experience on implementation, installation, testing, commissioning and operation / maintenance of such projects".

Q-7 Quality and standard of goods, like vehicles, equipments, machines, plants, devices, systems should be ensured in 3 stages:

a) Preparing tender documents (TD), specially technical specification.

b) Tender/proposal evaluation: TEC/PEC should be formed properly by honest, sincere and professionally skilled resource and evaluation should be done as per regulation. Process should be free from political influence.

c) Inspection on delivery, installation, testing, commissioning and $\mathrm{O} / \mathrm{M}$.

Ans.: Yes / No/ Partially

Graphical Representation

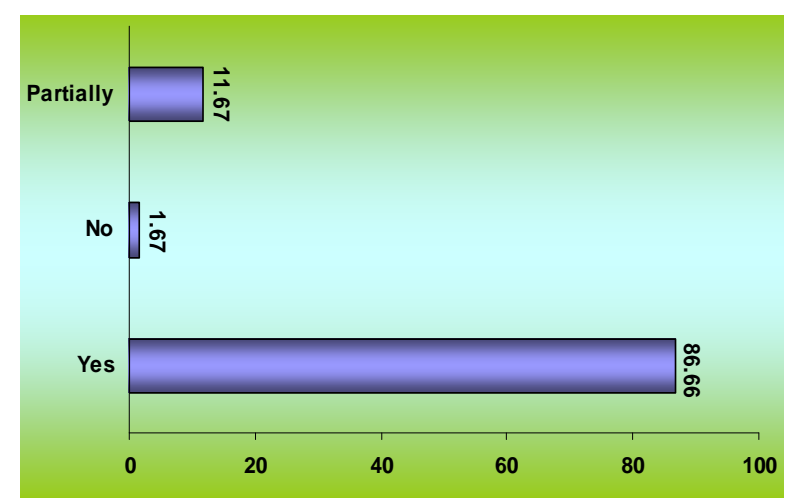

Which show that $86.66 \%$ of respondents agree with the suggestion for ensuring quality and standard of goods, like vehicles, equipments, machines, plans, devices and systems should be ensured in 3 phases as mentioned above.

\section{SUGGESTIONS ON CAPACITY BUILDING FOR SUSTAINABLE DEVELOPMENT:}

As per empirical outcomes following lacks, gaps or problems of existing PPM are found.

i) There are political pressure and influence on existing PPM.

ii) Human resources involved in public procurement have poor education and practices in honesty, morality and professional ethics.

iii) DPP, TD, PD etc. prepared by PE, are not $100 \%$ proper for ensuring quality and standard of procured goods, works and services.

iv) External members of the TEC/PEC play poor role on evaluation of Tenders/ Proposals

v) Tender evaluation is influenced by HOPE/Political leaders/Development partners.

vi) Tendering process is influenced by coercive/ collusive /fraudulent practices.

vii) Procurement efficiency is poor due to corruption, improper procurement plan and drawbacks of PPR.

viii) Tenderers / suppliers/ contractors of our country are not skilled to follow PPR.

To overcome above drawbacks in existing PPM, following suggestions for sustainable development are supported by the present study:

a) All universities should have sufficient courses (likely at least 3 courses, each having 3 credits in graduation 
level) on education and practices on honesty, morality and professional ethics. Course contents should be taken from religions and from life history of famous personnel of the history.

b) As approximately $75 \%$ of national budget is utilized in development projects, and engineers are mainly involved in development projects, all engineering graduation courses should include a course on Public Procurement Management.

c) All universities, providing engineering graduation, must ensure educational quality and standard up to professional level. To achieve such level of standard, universities must have co-operation with industries, so that students can conduct UG/PG research on industry's need based projects, that is on real time projects not only on academic projects.

d) There should be a realistic procurement plan for each development project, the procurement plan should be developed by team-work, team members should have experience on implementation, installation, testing, commissioning, operation maintenance of such projects.

e) Human resources involved in preparation of DPP, TD, PD etc. should have knowledge, skill and experience on procurement management, project management, organizational conflict management, quality management and implementation of such projects.

F) e-Tendering should be introduced as soon as possible.

\section{CONCLUSIONS}

This paper present a part of author's Ph. D research under supervision of Professor Dr. Zahidul Islam of the University of Dhaka. Research title was "Evaluation of Public Procurement Reforms for Sustainable Development in Bangladesh". Research field and findings are very much interesting and realistic to present situation and should be followed by the GoB. But as an academic research work and as per strategic analysis and procedure of the research, there may have some wrong facts, findings, feelings etc. So constructive suggestions and criticisms are appreciated

\section{REFERENCES}

\begin{tabular}{|c|c|c|c|}
\hline SI & Author(s) & Title & $\begin{array}{c}\text { Publisher, Edition \& } \\
\text { Year }\end{array}$ \\
\hline 1. & $\begin{array}{l}\text { M A } \\
\text { Mannan }\end{array}$ & $\begin{array}{l}\text { Evaluation of } \\
\text { Public } \\
\text { Procurement } \\
\text { Reforms for } \\
\text { Sustainable } \\
\text { Development } \\
\text { in } \\
\text { Bangladesh }\end{array}$ & $\begin{array}{l}\text { Ph. D Thesis, } \\
\text { December-1012 AWU, } \\
\text { California, USA. }\end{array}$ \\
\hline 2. & $\begin{array}{l}\text { CPTU, } \\
\text { IMED } \\
\text { MoP, GoB }\end{array}$ & $\begin{array}{l}\text { Training } \\
\text { Modules } \\
1,2,3,4 \\
\text { "National } \\
\text { Training on } \\
\text { Public } \\
\text { Procurement" }\end{array}$ & $\begin{array}{l}\text { Government of } \\
\text { Bangladesh (GoB)- } \\
2004\end{array}$ \\
\hline 3. & $\begin{array}{l}\text { CPTU, } \\
\text { IMED } \\
\text { MoP, GoB }\end{array}$ & $\begin{array}{l}\text { The } \\
\text { procedure for } \\
\text { implementati } \\
\text { on of PPR-3 }\end{array}$ & $\begin{array}{l}\text { Government of } \\
\text { Bangladesh (GoB)- } \\
2004\end{array}$ \\
\hline 4. & $\begin{array}{l}\text { David I. } \\
\text { Cleland } \\
\text { et.al }\end{array}$ & $\begin{array}{l}\text { Systems } \\
\text { Analysis and } \\
\text { Project } \\
\text { Management }\end{array}$ & $\begin{array}{l}\text { McGraw-Hill Book } \\
\text { Company } \\
\text { Third Edition-1983 }\end{array}$ \\
\hline 5. & E.M. Awad & $\begin{array}{l}\text { Systems } \\
\text { Analysis \& } \\
\text { Design }\end{array}$ & $\begin{array}{l}\text { Galgotia Publications } \\
\text { (P) Ltd. } \\
\text { Second Edition- } 2008\end{array}$ \\
\hline 6. & Grant et.al & $\begin{array}{l}\text { Principles of } \\
\text { Engg. } \\
\text { Economy }\end{array}$ & $\begin{array}{l}\text { John Willy and Sons } \\
8^{\text {th }} \text { Edition- } 1990\end{array}$ \\
\hline 7. & $\begin{array}{l}\text { Harvey } \\
\text { Maylor }\end{array}$ & $\begin{array}{l}\text { Project } \\
\text { Management }\end{array}$ & $\begin{array}{l}\text { Pearson Education } \\
\text { Third Edition-2000 }\end{array}$ \\
\hline 8. & J.A. Barton & $\begin{array}{l}\text { Asking the } \\
\text { embarrassing } \\
\text { question }\end{array}$ & $\begin{array}{l}\text { Public opinion } \\
\text { quarterly,-1958 }\end{array}$ \\
\hline 9. & $\begin{array}{l}\text { JH Anderson } \\
\text { et.al }\end{array}$ & $\begin{array}{l}\text { Survey } \\
\text { methods in } \\
\text { community } \\
\text { medicine }\end{array}$ & $\begin{array}{l}\text { Edinburg: } \\
\text { Churchil living stone- } \\
1999 \\
\text { Vol-9 }\end{array}$ \\
\hline 10. & $\begin{array}{l}\text { Jhon A. } \\
\text { White } \\
\text { et.al }\end{array}$ & $\begin{array}{l}\text { Principles of } \\
\text { Engineering } \\
\text { Economic } \\
\text { Analysis } \\
\end{array}$ & $\begin{array}{l}\text { John Wiley \& Sons } \\
\text { Second Edition-1984 }\end{array}$ \\
\hline
\end{tabular}

